\title{
Of Efik and English: Code Mixing
}

\author{
Offiong Ani Offiong \\ Department of Linguistics and Communication Studies, University of Calabar, Nigeria
}

Bassey A. Okon

Department of Linguistics and Communication Studies, University of Calabar, Calabar, Nigeria

\begin{abstract}
Code-mixing involves the deliberate mixing of two languages without an associated topic change. It is primarily used as a solidarity marker. It is not something brought about by laziness or ignorance as such, rather it requires the conversant to have a good knowledge of the grammar of the two languages and to be well aware of societal norms. It is a source of pride to bilinguals (Wardhaugh 1986). In this paper we examine code mixing from the interference dimension, looking at it from the phonological and inter-lingual angles. We discuss code-mixing because Efik people are not monolingual. To them, substantial command of English is a passport to the arena of globalization and competitive white-collar job market. Therefore mixing Efik and English is inevitable. Urbanization, education, government business and multilingualism have triggered the Efik people to learn English. A combination of research principles using unstructured forms of data collection research methods is used for this study which are (i) Participant Observation and (ii) In-depth Interview. This paper is rooted in the phonemic theory which models what happens to the languages when there is a mixing and interference. We used aspects of morphological and sociolinguistic models in the analysis. We have come up with the key findings which state that the grammatical items, rather than the lexical ones, are crucial to the identity of a language. Also a language may borrow lexical items freely assimilating or not assimilating them. We can again add that a language is on its way to losing its identity once it starts borrowing grammatical items from another language.
\end{abstract}

Index Terms - bilingualism, borrowing, code-mixing, morphological mixing, phonological transference

\section{INTRODUCTION}

The introduction of English which was deliberate to the Efik, speaking people of Nigeria, who number about five hundred thousand began with, first, the slave trading activities in the $17^{\text {th }}$ and $18^{\text {th }}$ century and secondly continued with the educational activities of the missionaries in the South-Eastern corner of Nigeria in the $19^{\text {th }}$ century. Offiong and Ugot (2012) assert that language contact is usually the reason for language shift as well as the reason bilinguals codeswitch and code-mix. Where contact exists and there is competition, the tendency is for the stronger language to draw more speakers towards it which thereby engineers code-switching. In the community where Efik is spoken, English is spoken by everyone. Different linguists and schools have delved into this study from the perspective of sociolinguistics, concentrating on the roles that English has been made to play as a second language (Offiong, 2004; Essien, 1995). Banjo (1983) indicated that some synchronic studies of the languages in contemporary Nigeria have also appeared... in which emerging Nigerianism in English are examined" (p.17). Studies have been carried out on code mixing from the perspective of interference - Efik to English and also English to Efik. Our concern for this study is on English interference on Efik.

This paper studies the phenomenon of interference of English in the kind of Efik very commonly spoken by hundreds of Efik Nigerians who are bilingual in their mother tongue and English. As mentioned by Banjo (1983,), this study "seeks not to be merely taxonomic, but to examine the constraints which appear to operate on the process of code mixing" (p.18). Such a study, it is hoped, may throw light on a possible hierarchy of primitiveness, among the grammatical categories, with possible implications for language learning.

Code mixing in languages is very common and strong among bilinguals the world over. For code mixing to be effective, the participants usually share a bilingual background. The phenomena which characterize code mixing are traced to language contact. Code mixing which is also referred to as linguistic interference is seen as a back-lash interference depending on whether it is the first language or second language which interferes in speech events.

Essien (1995) defines code mixing as "a language phenomenon in which two codes of languages are used for the same message communication" (p.272). As emphasized by him, "code mixing produces one and the same message as if it came from one code or language (ignoring the attitudinal information which code mixing may carry)"

In the study of code-mixing of Efik and English arises certain problems which have elicited the interest of this paper. The problems of interference are noticeable when one listens to an Efik-English bilingual speak. These problems are obvious at all levels of linguistics. The Efik-English bilinguals have the problem of expressing the English culture while using Efik and vice versa. Again, code-mixing and code-switching are major problems which are noticeable amongst these bilinguals.

Through this paper, bilinguals can be enlightened on the risk of losing their mother tongue entirely to foreign languages which implicitly is giving away their culture and attitude for the sake of their alien's way of life. For example, 
some educated Nigerians with the same mother-tongue cannot have private discussion without the use of English lexical items. This is apparent simply because the original lexical items of their mother-tongue can no longer be used independent of code mixing and code- switching with English words and sentences.

\section{A. Research Questions}

In this paper, we require the following research questions which serve as a guide to carry out the analysis. The answers will serve as part of the findings.

1. Can some sociolinguistics aspects of borrowing, code mixing and code-switching be traceable to the $\mathrm{L}_{2}$ interference in $\mathrm{L}_{1}$ among the educated Efik-English bilinguals?

2. Are code mixing predominant features in interference?

\section{B. Theoretical Framework}

Our framework is streamed lined into the phonological, morphological and sociolinguistics level of linguistics. The theoretical framework aids us properly analyze the data. It explains to us why certain phenomena are peculiar to certain languages and why exposure to different languages is acquired by children and bilinguals differently. The phonological level is more emphasized and this enabled us understand more clearly the knowledge surrounding the sound variables that exist in the different languages, Efik and English. The speech sounds are different in terms of number and categories in code-mixing. The phonemic theory aids us draw inferences and observations on the salient properties of the individual phonological features of Efik and English. The aim of this framework is to enabled us determine why Efik bilinguals find it difficult to pronounce English words well, why the level of errors amongst Efik speakers of English is high and why borrowing, code mixing and code-switching are common amongst the Efik-English bilinguals.

The phonemic theory aids us compare the segments in the two languages and we have viewed the phonological systems of Efik and English. This is done using the major class features of the two languages as will be seen in the analysis, which has to do with contrastive analysis of Efik and English. These features are revealed using the natural classes of segments. The comparative analysis begins with looking at consonants available in the languages, before analyzing the vowels and diphthongs. The phonemic analysis is a lee way of aiding us understand why the Efik-English bilinguals interchange certain segments for the ones they have in their language, and also explain what happens while code-mixing takes place. Even the prosthetic insertion used by some uneducated subjects is accounted for by this phonemic theory and this is analyzed in the discussion of findings.

Again, for a proper analysis of the phonemic study of this paper, we require Weinreich's model which is explained below. Weinreich's (1974) 'Interlingual identification of Expression and Content Unit Theory' is used. Here, Weinreich distinguished physically identical sounds or words in two or more languages. He used the Russian and English languages to illustrate his theory. A test of the theory involved the use of phonemes and semantic oppositions of the Russian /p/ and the English /p/ in which it was discovered that the definition of /p/ in English involved no restriction compared to $/ \mathrm{p} /$ in Russian. Using this inter-lingual theory in the present study, we identified identical phonemes of English and Efik and subjected it to serious scrutiny as produced by Efik English bilinguals. For instance /b/, /f/ and /i/ in both languages are graphically identical but with phonic differences. The inter-lingual and phonemic theories are used in analyzing the written and oral test designed for the educated bilinguals of Efik origin. In Efik and English, certain speech sounds like /i/, /e/, /u/. among others, are identical symbols with different pronunciation in English and Efik words. Also, there are few words of similar structure in both languages that constitute problems for the bilinguals if not identified and brought to their notice. This paper also marginally works with morphological and sociolinguistic framework.

\section{A Contrastive ANALysis OF EFIK AND ENGLiSH}

We will first use the syllable structure to analyze the contrast found in Efik and English before we view the major class features. This surely enables us understand what transpires within the bilinguals' mind.

At the lexical level, English has great influence on Efik speeches of Efik-English bilinguals. Many English lexical items borrowed and assimilated are restructured into Efik language's lexical pattern. The consonant clustering and close syllable features of loan words are re-structured to comply with Efik V-CV, CV, CV-C syllable structured as in the following examples

\begin{tabular}{|c|c|c|}
\hline English & & Efik \\
\hline 1. [bleid] & & [bled] 'blade \\
\hline CCVVC & & CCVV \\
\hline 2. [strin] & & [situiriy] 'string' \\
\hline CCCVC & - & CVCVCVC \\
\hline 3. [tin] & - & [tian] 'tin' \\
\hline $\mathrm{CVC}$ & - & CVVC \\
\hline 4. [gla:s] & - & akrasi] 'glass' \\
\hline CCV: C & - & VCCVCV \\
\hline 5. $\left[\mathrm{ti}: \mathrm{t} \int \partial\right]$ & - & [titia] 'teacher' \\
\hline
\end{tabular}


$\mathrm{CV}: \mathrm{CV}$

CVCVV

The above examples are able to show the syllable structures of the two language especially using lexical items borrowed from English into Efik. During code-mixing by the Efik bilinguals, the borrowed words are adapted with ease making interference venerable.

As a way of comparing the segments in the two languages, we had to view the phonological systems. This was best done using the major class features. These features are revealed using the natural classes of segments. The comparative analysis begins with looking at consonants available in the languages, before analyzing the vowels. Efik has twelve (12) consonants and two semi-vowels (Noah, 2004). English on the other hand has twenty four (24) consonants (I.P.A.). The examples of the natural classes are recognized as seen in (1) and (2) below:

\section{1) Consonants:}

Stops

Fricatives

Affricates

Nasals

Lateral

Liquid

Semi-vowel

2) Vowels:

Vowels

$\begin{array}{ll}\text { Efik } & \mathrm{p}, \mathrm{b}, \mathrm{t}, \mathrm{d}, \mathrm{k}- \\ \text { English } & \mathrm{p}, \mathrm{b}, \mathrm{t}, \mathrm{d}, \mathrm{kg}, \\ \text { Efik } & \mathrm{f},-,-,-, \mathrm{s},-,-,-\mathrm{h} \\ \text { English } & \mathrm{f}, \mathrm{v}, \mathrm{\theta}, \mathrm{d}, \mathrm{s}, \mathrm{z}, \mathrm{S}, \mathrm{d}, \mathrm{h} \\ \text { Efik } & --,--, \\ \text { English } & \mathrm{t}, \mathrm{d} \\ \text { Efik } & \mathrm{m}, \mathrm{n}, \mathrm{y} \\ \text { English } & \mathrm{m}, \mathrm{n}, \mathrm{y} \\ \text { Efik } & - \\ \text { English } & \mathrm{l} \\ \text { Efik } & \mathrm{r} \\ \text { English } & \mathrm{r} \\ \text { Efik } & \mathrm{w}, \mathrm{y} \\ \text { English } & \mathrm{w} . \mathrm{j} .\end{array}$

\section{Efik}

English - i, e, $\mathcal{E}, \mathrm{a}, \mathrm{u}, \mathrm{o}, \mathrm{o}$

i, e, $\mathcal{E}, æ$, a, o, o , ə, ^, u, $\mho$, , , о ,

From the examples of the consonants and vowels in the two languages we have been able to recognize the natural classes which accounts for the errors noticed in the speeches of Efik speakers. We have discovered why Efik speakers have pronunciation problems in their use of English. The phonemic speech sounds of both languages are clearly different both with significant similarities. Efik has the following seven (7) phonemic vowels (Noah, 2004, p. 588), while English has the following twelve (12) vowels (I.P.A.) as seen and recognized above. Diphthongs are found in English and Efik. While English has eight (8) (I.P.A.), Efik has four (4) (Cook, 1985).

To understand what transpires in the minds of the Efik speakers at the phonetic and phonological level and while code-mixing is taking place, we have looked at the consonant and vowel speech sounds of the two language; these has aided us properly compare and contrast the different segments and study why Efik speakers, especially the uneducated ones, make mistakes in their pronunciations and also why they borrow and code-mixing.

\section{Functions OF CODE MiXing}

Code-mixing is common among the educated class who speak English and a Nigerian language, in our case Efik. It is hardly observed between any two Nigerian languages. It differs from code switching in that, while two codes are employed, only one set of hearer/listener who understands the code used by the speaker is involved (Essien 2000, p.4). Code-mixing is seen as a phenomenon in which two codes or languages are used for the same message and borrowing as the copying of a linguistic item into another speech form. Essien distinguish between code-mixing and borrowing from the perspective that borrowing is commonly restricted to vocabulary or lexical items. But one who code-mix does not do so constantly or permanently as he does in borrowing. The data of performance from code-mixing reveal that the same items are usually not mixed consistently by more then one person or even the same person (Essien 2000, p.4).

Code mixing has its different linguistic functions. There are so many situation in a language were words are not readily available to express a situation or to name an object. Efik hastily rushes to English for such bailing out. Also code-mixing serves as an intimacy functions among friends and relations. It portrays a sign of closeness amongst the interlocutors making them feel more at home between themselves. Essien (2000) calls this "a socio-psychological function".

Code-mixing has its own grammar, i.e. it follows certain system of rules which may be language dependent or language independent. Essien (2000) suggests that "while code-mixing may be more or less ad-hoc in terms of selection of mixing items, borrowing is more stable. A person or community that borrows some items is likely to repeat the same items as the need arises" (p.5). Examples are found in Efik.

1. nyom ndidia rice ye stew ye beans

'I want to eat rice and stew and beans'

2. mman ndep an American car 
'I had bought an American car'

These mixing constructions are possible because both Efik and English share the construction in which the verb is followed by the object. For the purpose of clarity, it is necessary to mention here that the domain of code mixing is the sentence, whereas the domain for switching is the discourse. In sociolinguistics studies like this, it is necessary to distinguish between code-mixing and code- switching. These two terms have tended to be used in a somewhat confusing manner in some linguistic works. We are more interested in code-mixing.

\section{LINGUISTIC ANALYSIS}

Code mixing is a phenomenon which occurs in the Efik speech of practically every Efik person who is bilingual in Efik and English. The degree of mixing may vary very widely from one occasion to another. The English mixed in isolation with Efik are in most cases, lexical items as illustrated by the following sentences.

3. nọ Okon beans odo

'Give Okon the beans'

4. nyom ndiduk moto odo

'I want to enter that motor car'

5. di bọ mi eyen emi because akak mi

'come and collect this child because I am tired'

6. me examine enye

'I have examined him'

Using Banjo's (1983) analysis to examine the sentences above, we observed the following. Firstly, the loan words from English to Efik are unassimilated. In this case, the pronunciation of the words would be approximately close to the way they are pronounced in an English utterance. There is a pressure of Efik phonology occasioned by the context that is considered. In cases like this, syllabic tones are introduced to replace lexical stress. Thus 'because' in (5) becomes bécàùse.

From the examples above, we have noticed that there are loan words which are either nouns in (3) and (4), a predicate adjective in (5) and a verb in (6). The occurrences of all of these loan words vary depending on the categories. Noun and verbs can occur as loan words especially when the words do not have its equivalent in the Efik language. 'Motor' for instance has a translated version in Efik - ubom isọn, but it is hardly used. It is more convenient to use 'beans' instead of 'okoti' because it is less cumbersome. On the whole generally, nouns and verbs that are available in Efik are more used by the bilinguals than the English equivalent. It is rare to see an Efik bilingual use nouns like 'head' hand' 'nose' etc, and verbs like 'see', 'says', 'eat etc. The reason is that these items are so basic in every language that it is not necessary for one language to borrow them from another. Several factors may be attributed for these tendencies. It can be interpreted that words not available in Efik are immediately borrowed from English. The educated bilinguals are more prone to this. However, this is not always the case, the degree of code mixing is indicative not only of the speaker's bilingualism, but also of his relative communicative incompetence in his mothers tongue (Banjo 1983). This analysis clearly answers research question 1. It shows that sociolinguistics aspects of borrowing and code-mixing are traceable to the $\mathrm{L}_{2}$ interference in $\mathrm{L}_{1}$ among the educated Efik-English bilinguals.

Code mixing in Efik has obvious differences, when the words borrowed are examined. Nouns, verbs, adverbs, prepositions and adjectives when loaned from English are affected by the environment in which they occur. The interference can be phonological, that is, the bilinguals will try using the loaned words with a foreign accent or stress or rhyme or intonation. The interference can also be grammatical as per the bilinguals missing loaned word orders or using pronouns and determinants, or tense and mood of the loaned language. Code mixing is further seen as interference at the lexical level, which involves the borrowing of words from English and converting them to sound more natural in Efik. Orthographic interference includes the spelling of one language affecting the other, in our case English spelling affecting Efik.

Examining the phonological transference of elements of Efik to English, we had earlier noticed that the borrowed word in example (5) lacked stress, but imbibed tone which is usually not found in English. All the borrowed words from English becomes tonal as soon as there are mixed with the Efik language.

At the grammatical level, we notice the occurrence of change of word order which is analysed as morphological mixing. These simple elements of partial phrase illustrate it:

7. Enye iki playke ball odo

*He did play not ball that

'He did not play that ball'

8. Bassey iki benefitke ke mbubehe odo

*Bassey did benefit not in business that

'Bassey did not benefit in that business'

9. Ete mi ọdrọp mi

*Father my he drop me

'My father dropped me' 
The transference of elements of the verb in the above samples are mostly occurrences of verbs. From examples (7) and (8), it is observed that the English verbs introduced in the two sentences had the '-ke suffix attached to them. 'ke' in Efik is a negation morpheme which is morphologically adapted to Efik. This also applies to 'odrop' meaning he dropped.

Still analyzing the occurrence at the grammatical level, we noticed that tense is never borrowed separately or along with loan verbs in isolation:

10. Mman examine enye

I past examine him

'I examined him'

This will lead us to conclude that in Efik, it is the syntactic rules of Efik that operate. As confirmed by Banjo (1984) of the Yoruba language, Efik which has similar features has number borrowed with the words.

11. Mo kut mme dresses mi

*I have seen dresses my

'I have seen my dresses'

Efik like most Nigerian languages neither marks tense nor number morphologically (Offiong 2008), and it is interesting that, in code-mixing, number should be borrowed along with nouns while tense is not borrowed with verbs. We are therefore tempted to arrive at the fact that the category of tense is more basic than that of numbers (Banjo 1983).

Interference at the lexical level affects code-mixing from the perspective of words borrowed from English and converting them to sound more natural in Efik. Examples of such borrowed lexical items are:

$\begin{array}{ll}\text { 12. Efik } & \text { English gl } \\ \text { Tumbit } & \text { tumbler } \\ \text { Tian } & \text { tin } \\ \text { Suọp } & \text { soap } \\ \text { Akrasi } & \text { glass } \\ \text { Tiande } & \text { candle } \\ \text { Edoplen } & \text { aeroplane } \\ \text { Ben } & \text { pen } \\ \text { Tọsin } & \text { thousand } \\ \text { Titia } & \text { teacher }\end{array}$

The examples in (12) are viewed from the perspective of the lexical level. These are analysed from the perspective of orthographic and phonological interference. The above are also answers to research question 2. The phonemic theory caters for these adapted words borrowed from English.

Analyzing code-mixing from the perspective of sociolinguistics, we noticed that bilinguals used several lexical and phrased mixes. The illustrations are seen below:

13. Tian ke eda esin udia ebua

*Tin is used to put food dog

'Tin is used to put the dog's food'

14. Men suọp odo nọ mi

*Carry soap that give me

'Give me that soap'

15. Nko duk edoplen nka Lagos

*I past enter aeroplane I go Lagos

'I entered an aeroplane to Lagos'

16. Nọ mi kọp uwon mmọn odo edide silibe

* Give me cup drink water that whch is silver

'Give me that silver cup'

17. Nyom emen akrasi odo enim ke okpokoro

*I want you carry glass that you keep on table

'I want you to take that glass and keep on a table'

From the above examples, we observed that there were phonological and morphological reasons for the mixing occurrences, pointing to the greater complexity of the Efik lexical items in comparison to the English equivalent from all of these. Hoffmann (1991) indicates that mixing may occur for a number of reasons, the most important of which can be summarized as follows:

i. If an item has been acquired in one language but not yet in the other, the child may use the one device he has available to express a certain lexical or grammatical meaning.

ii. If an item is more complex, or less salient, in one language, the young bilingual may make use of the corresponding one from another.

iii. If a child is exposed to mix input, he will often respond with mixed production, (p.107).

As it entails mixing, observers of bilingual language development agree in their reports that mixing diminishes over time, but differ in the explanations that they offer. Hoffmann (1991) further says: Some studies have tried to find out 
why some children mix more than others and why there is a difference in the pattern of their languages separation. A number of inter-connected factors are seen to be operating, which can be classified as relating to:

a. The language input

b. The linguistic development

c. The general cognitive development

Code mixing events for this paper are intra-sentential. The intrusion of English words occurs at initial, medial and even in final position of Efik sentences.

18. Momi, nyom ndidia udia

'Mummy, I want to eat'

19. Taxi ọdrọp mi idaha mi

'It is a taxi that just dropped me'

20. Tian ke iko odo edi

'That container is made of tin'

21. Dọya mi okot mi

'It is my lawyer that called me'

22. Butter bread nọ mi

'Spread the butter on the bread for me'

23. Ete esie ete ke ima islap enye

'His father said that he slapped him'

24. Okon edestrọi mme nkpọ odo

'Okon destroyed those things'

25. Nyom ndiduk edoplen

'I want to enter an aeroplane'

26. Ka ke nime telefision

'Go and switch off the television'

Number (18) - (22) have examples of initial intrusion of English lexical items. (18) - 21) are all noun phrases while (22) stands out as a verb phrase. Noun phrases are more commonly used by Efik/English bilinguals when compared to verb phrases. (23) and (24) are found in Efik sentences at the medial positions and the perform grammatical functions some of which are noun phrases while some others are verb phrases. Examples (25) and (26) are illustrations of intrusions that concern the final position. Our observation here is that the English lexical items are all nouns which make it easily analyzable.

\section{DISCUSSION OF FINDINGS}

In articles like this, it will be wrong to discuss code mixing without looking at bilingualism. Fishman (1960) defines bilingualism as "equal and advanced mastery of two languages" (p15). However, his contributions on the same subject, particularly the natural bilinguals, render an earlier definition by him as restrictive in scope: Weinreich (1974) defines bilingualism "as a practice of alternatively using two languages while the person involved are called bilinguals". He also, like other scholars, asserts that bilingualism and interference phenomenon are inevitable products of languages in contact". In his words, "two or more languages are said to be in contact if they are used alternatively by the same persons while the language using individuals are thus the focus of the contact"

Bilinguals are the main carriers of lexical items from one language into the others. What happens to the borrowed lexical items vary from one lexical items to another. In the Efik language case, some words are assimilated, while others are directly lifted without assimilation. Examples (12) are English words assimilated like bọl for 'ball', tian for 'tin', bodisi for 'police' tọsin for 'thousand' etc.

What we have noticed in the words transferred and assimilated into Efik is that they were restructured because of the vast difference in the phonemic structure of the two languages in question. Because Efik has no [p] segment in its word initial position, [b] is substituted in words like pen which becomes 'ben', babru for 'paper', bon for 'pound' etc. There are various others examples like doya for 'lawyers', ayon for 'iron' etc. These words had to be restructured because the phonetic systems of the two languages are different.

As we study these loan words, we noticed certain words that were so transformed that they became unrecognizable. Efik words like 'tian, suọp, edisi babud, dọya' are English words adopted into Efik. Except with special language training, monolinguals and even some bilinguals, will not recognize these words as English words. We are able to confirm that English words in Efik transferred their origin phonological features into Efik and by which they were distinguished as loan words.

Just as we had noticed the assimilated words, we also noticed the unassimilated English loan words in Efik by the Efik bilinguals. The English words under this category occurred in the analysed Efik discourses with their original pronunciation and spelling. In some Efik discourses as in English and written to express Efik meaning without loss of identity. The following words are frequently used. "Post office box, email, computers, window, tyre, table, match, speaker, air hostess, House of Assembly and many more like that. 
The reason for the unassimilation of the words indicated above are either that the Efik-English bilinguals lacked the knowledge of the words in Efik or the words are not available at all in Efik. Offiong (2005) quotes Rowland (1965) that a bilingual uses unassimilated words due to his ignorance or unfamiliarity with the appropriate native words" (p.116). Eka (1995) observed that most African languages are spelt the way they are pronounced and to move from a system in which words are pronounced the way they are written to one in which the spelling is largely different from the pronunciation constitute a big problem, (p.67).

The English words loaned into Efik without changing the structures poses problems for the examined bilinguals; the results of which are mispronunciation of the English words. Loan word adaptation implies that speakers will show faithfulness to the source word and at the same time try to make the loanwords conform to their native segmental inventory, phonotactic constraints and morphological system (Kenstowicz and Suchato 2006, Mensah 2011). In reality, the Efik - English bilinguals are confronted with the problem of not operating perfectly well both in Efik and in English. They are therefore victims of imperfect competence in both languages and thereby qualified to be referred to as language confusionist.

\section{CONCLUSION}

Any time code-mixing is discussed, the following areas must be looked into, language contact, interference, borrowing and loaning. Even code-switching which is mixing on a larger scale must also be mentioned. Code-mixing provides continuity in speech rather than presenting interference in language, in our case, Efik benefiting from English.

This study sought to explore the problem of code-mixing among Efik - English bilinguals. These bilinguals code mixed because of lack of rich vocabulary in Efik. Some of them code mix for reasons of identifying with prestigious language, in this case English. We can therefore infer that, with Efik - English bilinguals, code-mixing is a conscious effort. We can safely conclude that code-mixing should not be seen as a linguistic sabotage directed against an indigenous language - Efik, but as a conscious display of knowledge of the English language.

A number of conclusions can be drawn from this study, some of them confirming the findings of other studies. We can rightly affirm that the grammatical items, rather than the lexical ones, are crucial to the identity of a language. A language may borrow lexical items freely assimilating or not assimilating them. We can also add that a language is on its way to losing its identity once its starts borrowing grammatical items from another language. This study shows also that blocks of constituents containing grammatical items may be borrowed.

From this study we can further conclude that the Efik people had contact with the English language since the 1700s. They have benefited a lot from the English language in terms of borrowed words etc. The level of interference even though high, has been more of benefit to the Efik people. Finally, we can say that the language rules of the host language operate. This is hardly surprising, since mixed sentences are regarded as sentences of the host language. When there is contact between two languages like Efik and English, the linguistic features of one language interferes with the other one. Interference is viewed as the transference of elements of one language to another at various levels including phonological, grammatical, orthographical among others.

\section{REFERENCES}

[1] Aye, E. U. (2000). The Efik people. Calabar: Glad Tidings Press.

[2] Banjo, A. (1983). Aspects of Yoruba/English Language Mixing. Journal of Nigerian Languages: 1 (2), pp. 17 - 26.

[3] Cook, T. L. (1985). An integrated phonology of Efik. Dordrecht: I. C. G. Printers.

[4] Eka, D. (1995). English Pronunciation. In M. Udofot (Ed), Current Trends in Educational Practice. (pp. 1-15). Uyo. Emason Ltd.

[5] Essien, O. E. (1995). The English Language and code mixing: A case study of Ibibio. In A. Bamgbose (Ed) New English: A West African Perspective (pp. 269 - 282). Ibadan: Mosuru Publishers and Booksellers.

[6] Essien, O. E. (2000). Code-Switching and Code-Mixing In. O. Ndimele (Ed.) Kiabara Journal of Humanities (pp. 1-8) 6 (11). Port Harcourt: Uniport Press.

[7] Fishman, J. A. (1966). Bilingual Sequences at the Societal level. Teaching English to speakers of other language series 1 (2) pp $139-144$.

[8] Fishman, J. A. (1969). Sociolinguistics. Massachusetts: Newbury House.

[9] Hoffman, C. (1998). An Introduction to Bilingualism London: Longman Groy Ltd.

[10] Kenstowicz, M and Suchato, A. (2006). Issues in loan word adaptation: A case study of Thai. Lingua. 116. 7: 921-949.

[11] Mensah, E. (2010). The morphosyntax of code-mixing: the Efik-English perspective. Concentric: Studies in Linguistics. 36 (2), 235-256.

[12] Noah, P. (2004). Towards a more phonemic Efik orthography. In O. Ndimele (Ed.), Language \& culture in Nigeria: A festschrift for Okon Essien (pp. 587-594). Port Harcourt: Emhai Press.

[13] Offiong O. A. (2004). Concept of bilingualism and cognitive functioning in Efik/English speakers. International Journal of Linguistics and Communication (Maiden edition) pp. 215 - 224.

[14] Offiong, O. A. (2008). Direct and Reverse Interference: The Case of English and Efik. Unpublished Ph.D Dissertation. Faculty of Arts, University of Calabar.

[15] Offiong, O. A. and Ugot, M. I. (2012). Minority language Maintenance: The Case of the Efik Language in South Eastern Nigeria. Theory and Practice in Language studies. 2 (12), 2491-2499.

[16] Weinreich, U. (1974). Languages in contact: Findings and problems. The Hague: Mouton. 


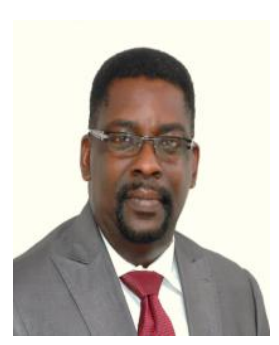

Offiong Ani Offiong is an Associate Professor in the Department of Linguistics and Communication Studies, University of Calabar, Calabar, Nigeria. He has been the Head of Department (2008-2010) and he was the Sub-Dean of Faculty of Arts, 2010 - 2012. He is currently the Chairman of the post graduate committee in the Faculty of Arts in the University. He holds a B.A. (Hons.) in Linguistics, a Masters and a $\mathrm{Ph}, \mathrm{D}$ in Sociolinguistics in 1983, 1986, and 2007 respectively. Dr. Offiong is listed in the Linguist list. A member of the Linguistic Association of Nigeria. He has published more than 20 articles in reputable journals including the TPLS journal.

Bassey A. Okon is an Associate Professor in the Department of Linguistics and Communication Studies University of Calabar, Calabar, Nigeria. She has been the Head of Department (2004-2006), a member representing the Faculty of Arts in the University Senate. Dr. Bassey Okon holds a B.A. (Hons.), a Masters and a Ph.D all in Linguistics. She has about 34 publications in different journals, books and conference proceedings. 